\title{
Glocal Initiatives in Fostering Collaboration in Pedagogical Transformation: Lessons From Universiti Teknologi Mara, Malaysia
}

\section{Wan Zumusni Hj Wan Mustapha}

Academy of Language Studies, Universiti Teknologi MARA Negeri Sembilan Campus, MALAYSIA ORCID:

Wan Zumusni Hj Wan Mustapha: https://orcid.org/0000-0002-7394-549X

\section{Abstract}

Researchers have long propagated self-directed, lifelong learning as a way forward in grooming human capital. Language learning must transcend beyond the traditional classroom, which uses chalk and talk methods with a heavy reliance on textbooks, towards more flexible, learner-centered methods. The challenge of a lack of suitable teaching materials that are accessible for students outside the classroom can be overcome by using authentic reading materials available online and offline. The

Corresponding Author: Wan Zumusni Hj Wan Mustapha zumusni178@uitm.edu.my

Published: 11 March 2021

Publishing services provided by Knowledge E

(c) Wan Zumusni Hj Wan Mustapha. This article is distributed under the terms of the Creative Commons

Attribution License, which permits unrestricted use and redistribution provided that the original author and source are credited.

Selection and Peer-review under the responsibility of the AICLL Conference Committee. COVID-19 pandemic has pushed the digital learning agenda and has changed the way educators think and execute their teaching and assessment. It has certainly changed the way they work, live and communicate in their professional and personal lives. This paper addresses the challenges faced by English as a second language educators teaching during the pandemic and how pedagogical transformations can be done. Using developmental action research, this paper presents The Reader's Digest story by tracing the history of academic-industry collaborations to enable transformation in teaching and learning through innovations at the tertiary level.

Keywords: teaching second language, reading beyond classrooms, academic-industry collaborations, teaching innovations, developmental action research

\section{Addressing local and global challenges in teaching English as a second language}

Researchers have long propagated self-directed, lifelong learning as a way forward in grooming human capital. The COVID-19 Pandemic has pushed the digital learning agenda into making language learners to be more autonomous and resourceful. It has certainly changed the way educators work, live and communicate in their professional and personal lives. The major shifts on how industries adapt to the "new normal" and professionals change the way teaching and learning are conducted. 
Thus, the role of universities in continuing the teaching and learning must include educating the graduates to have adequate capabilities in meeting uncertain future challenges. Educators has no choice but to adopt it while teaching remotely. The pandemic has disrupted more than $\mathbf{3 0 0}$ million students worldwide but with the right tools and knowledge, the teaching and learning shall continue from anytime and anywhere.

Asynchronous teaching and learning have been practiced in Universiti Teknologi MARA (UiTM) with Massive Open Online Courses (MOOC). MOOC allows access to infinite number of participants, inexhaustible interaction and a variety of learning materials. MOOC platform also provides introductory courses from some of our expert academics to help the learners acquire new knowledge and skills for their personal development and enlightenment.

\section{Challenges in teaching critical reading and creative writ- ing}

Educator and learners of English as a second, or in Indonesia and other ASEAN countries, a foreign language, are finding teaching and learning critical reading as challenging to educators. The challenge to teach students at all levels, from primary to tertiary is even greater in the digital era where students would rather spend time online and on gadgets than flipping magazines to read (Hopper, 2005). Reading and writing have been seen as solitary, boring and individualized among ESL learners.

Language learning must transcend beyond the four-walls of language laboratories and classrooms and not just relying on chalk and talk as well as textbooks. One of the challenges is lack of suitable teaching materials that are accessible for students outside the classroom. These authentic reading materials offer a variety of reading materials to be adapted to learners' needs.

As a receptive skill, reading is fundamental in developing other language skills namely writing, listening and speaking. Therefore, students must be good in reading in order to be successful in their academic pursuit. The heavy dependence on textbooks has stifled students' creativity and critical thinking, making reading and writing even more uninteresting. Engaging students in reading a textbook outside the classroom or doing writing activities would be next to impossible as students prefer to do other activities than reading. However, reading a textbook outside the classroom would be next to impossible. It is also important to create a reading program that involves active participation in a fun environment. 
Acculturating reading for pleasure would combat social exclusion and raise educational standards (Department of Education, UK). Reading for pleasure offers resources that are unavailable in an education setting (Muchow, 2015). Heavy dependence on the reading textbook makes students struggle to understand the English language textbooks and they might find the textbooks irrelevant, uninteresting, and culturally unfamiliar (Nordin and Eng, 2017). Stoffelsma, \& Spooren (2017) proposed using education research design in studying the issues, problems and possibilities in an intervention program in improving academic reading proficiency.

\section{Pedagogical transformation -- The Reader's Digest story}

Reader's Digest was formerly based in Chappaqua, New York, and now has its headquarters in New York City. The magazine was founded in 1922, by DeWitt Wallace and Lila Bell Wallace. For many years, Reader's Digest was the best-selling consumer magazine in the United States. According to Mediamark Research (2006), it reaches more readers with household incomes of $\$ 100,000+$ than other magazines such as Fortune, The Wall Street Journal, Business Week and Inc. combined.

The global editions of Reader's Digest reach an additional 40 million people in more than 70 countries, with 49 editions in 21 languages. It has a global circulation of 10.5 million, making it the largest circulation magazine in the world. It is also published in Braille, digital, audio, and a version in large type called Reader's Digest Large Print. The magazine is compact, with its pages roughly half the size of most American magazines. Therefore, in the summer of 2005, the U.S. edition adopted the slogan: "America in your pocket." In January 2008, it was changed to "Life well shared." In South East Asia, it is available only in Singapore, Malaysia, and Phillipines. Reader's Digest Indonesia was published by PT Sarana Media Internasional since 2004 until October 2015.

Reader's Digest magazines offer solutions to educators to organize outdoor reading activities which are flexible, adaptable, cost and timesaving. Students need to keep up with what is going around the world and having a current magazine that they can afford to buy would encourage reading beyond the classroom. Reader's Digest magazine was introduced to Diploma and Degree students in UiTM Kelantan in 2003. The developmental research method (Richey \& Klein, 2005) is used to in planning (framing the problem and identifying the participants and limitations of the innovative way of teaching beyond the classrooms), creating the module (using needs assessment in developing the outdoor critical reading and creative writing module) and designing 


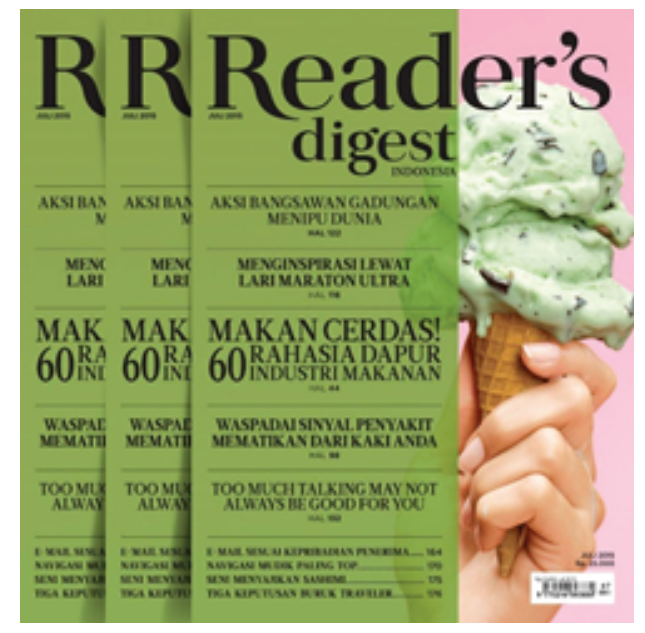

Figure 1: Reader's Digest Indonesia (2004-2015)

a generic module that can be adapted according to different levels of students. It was chosen because the magazine, as an authentic reading material also pictures and graphics and offer students a natural source of language use (Vavla, 2009).

The articles in newspapers and magazines offer current issues in various genres, making them as excellent choices as they are easily available and inexpensive for university students (Al Nafisah and Al-Shorman, 2011). Secondary school students' motivation for reading would be highly influenced by teachers than family as found by Ulper (2011) that students' loyalty towards their primary and secondary school teachers correlates positively to their motivation to read.

The experimental research in UiTM Kelantan, Malaysia revealed that students' performance in English language learning improved with the use of RD magazines and worksheets in the classrooms (Wan Mustapha, Abd. Muin and Wan Hassan, 2005). Reader's Digest magazines as supplementary materials in the classrooms for three months. Apart from an increased motivation and positive attitudes towards reading outside the classrooms, students in the experimental groups reported to have increased their scores in the reading exam from $2.3 \%$ in the pre-test to $14 \%$ in posttest for those who scored 41-45 marks.

In 2016, Academy of Language Studies, UiTM Negeri Sembilan, Seremban Campus and Reader's Digest Asia Pacific co-organize "Critical Reading and Writing Workshop with Reader's Digest". The workshop on Reader's Digest were attended by UiTM Degree students, secondary school students, teachers and district education officers in Negeri Sembilan. It was a good start to raise awareness on outdoor based reading activity and using authentic materials beyond the ESL classrooms. The aim of the workshop was to share ways Reader's Digest can be incorporated into lessons inside and outside the 


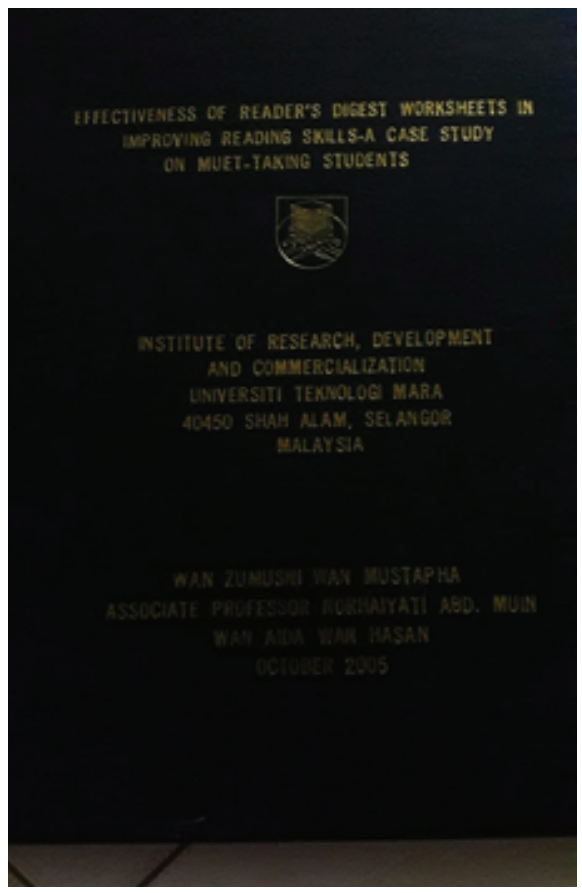

Figure 2: Reader's Digest research report

classroom. This is towards fostering a love for reading and guiding students to practice reading independently outside the classroom.

During the workshop, a questionnaire was distributed to the participants namely, the lecturers and students. Findings from this survey revealed that $98 \%$ of the participants have read Reader's Digest magazines; 59\% was introduced at their respective schools or universities, $33.3 \%$ by family and $7.1 \%$ by friends. $55 \%$ of the teachers and district education officer believed that RD magazines would help their students to improve vocabulary and writing skills. However, alarmingly only $20 \%$ would use them as teaching materials in their classrooms.

From being a supplementary reading material, Academy of Language Studies, UiTM Negeri Sembilan included Reader's Digest in one of the activities during Language Week. Explorace, the most popular activity among the students involved students working outdoor in groups to work on critical reading and creative writing task. The two and a half hour outdoor activities were conducted in a fun, interactive and engaging way using Reader's Digest magazines. Students ran from the first check point to the last check point in their respective groups. At each check point, they did some tasks on critical reading and creative writing. At the end of the activity, the teams are judged not only on the completion of task but also on the teamwork, speed and creativity and the best team won a prize. 


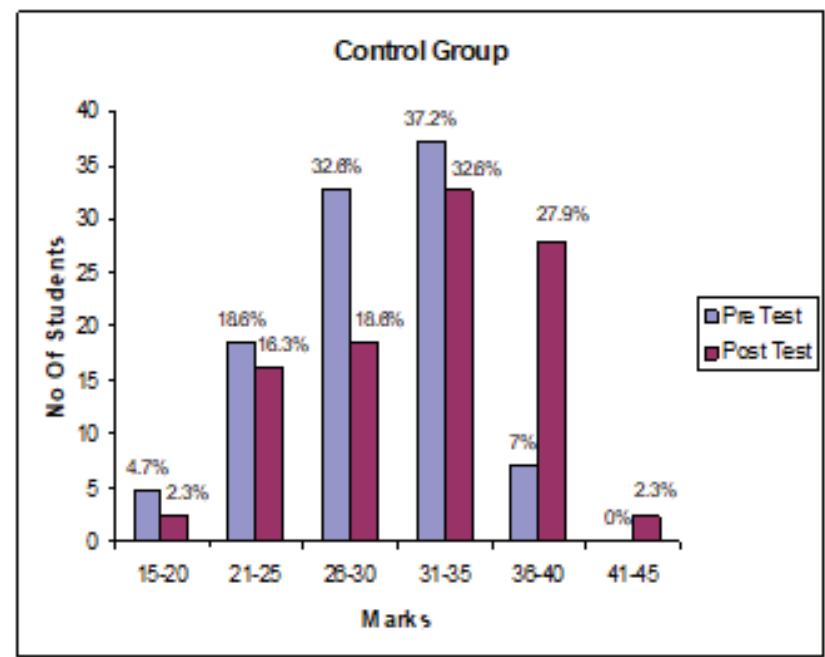

Figure 3: Pre and post test results for the control group

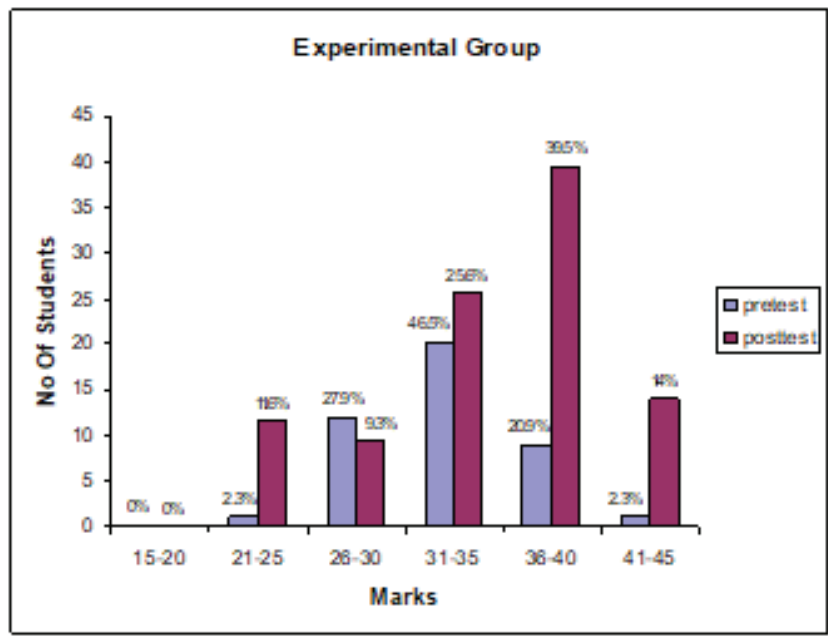

Figure 4: Pre and post test results for the experimental group

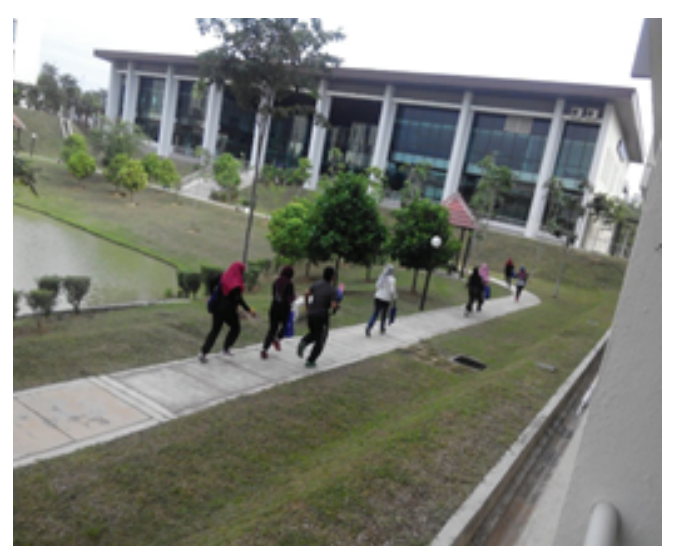

Figure 5: Explorace at UiTM Seremban

The Reader's Digest Reading Program using digital worksheets has been implemented since 2003 in UiTM but CReW RD was an extension of the classroom activity to 
take reading outside the classrooms. There are many critical reading and creative writing activities that can be done to allow students to learn vocabulary, sentence construction and paragraph writing. $\mathrm{CReW}$ RD demonstrates that learning can be active and fun through reading and writing using authentic reading materials such as a magazine.

Although Reader's Digest magazines and worksheets have been used as supplementary materials since 2003, CReW RD 1/2016 started as a workshop for teachers and students in knowledge sharing with community. Following the success of CReW RD 1/2016, CReW RD 2/2016 was conducted, and CReW RD Kit was showcased during Academy of Language Studies Language Week for Degree students. CReW RD 2/2016 was conducted in an outdoor amazing race format with ten teams of degree students.

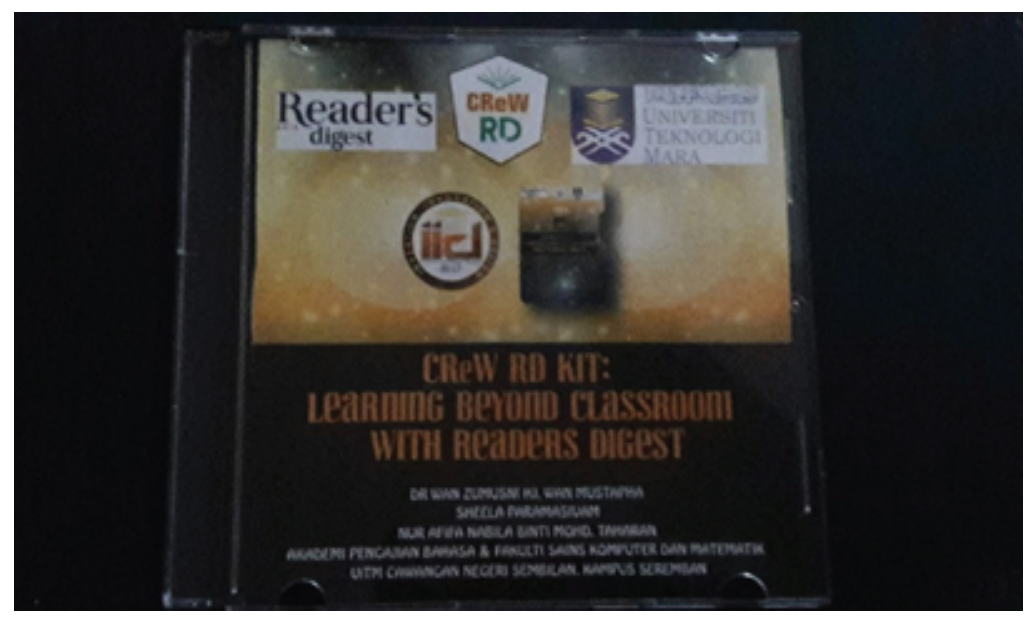

Figure 6: CReW RD KIT CD

The kit contains complete guide for the teachers, as the organizer of CReW RD in their respective schools to organize the outdoor program. The kit which contains some modules were designed to conduct reading and writing activities using Reader's Digest magazine beyond the classroom. Reader's Digest Asia Pacific sponsored the magazines to be used for each CReW RD. When the school later decided to subscribe the magazines for the students, Express Subscription Sdn. Bhd. Supplies the magazines at $33 \%$ discount with free worksheets and postage.

The module was tested and refined at several secondary schools in Malaysia. The schools are located in rural and urban areas, including boarding schools. Students who participated in the "Critical and Creative Reading and Writing using Reader's Digest program" or CReW RD are in Form 1, 2, 4 and 6 ranging from 100 to more than 300 participants in each program. After CReW RD Module is tested, the module is compiled in a book.

In another activity in UiTM Seremban, during the Week Without Walls (WWW), students were encouraged to post on their social media accounts such as Instagram 

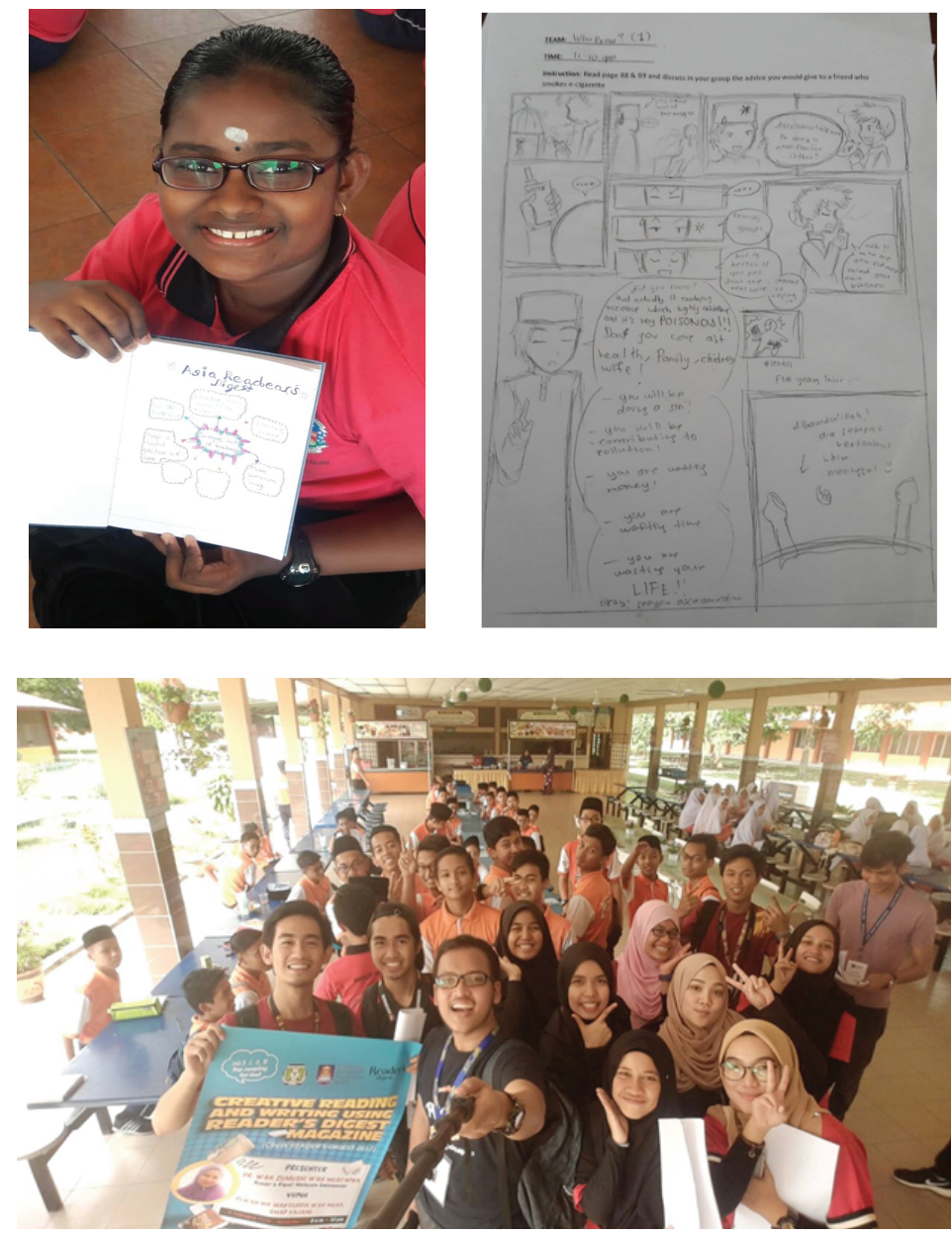

Figure 7: CReW RD at schools

to share their reading activities with captions. Such activity can be done during the pandemic where students share their reading activities at home or outdoor, whenever possible, tag their friends and put an interesting caption. The most important and exciting part is to share their joy for reading with their parents and the parents also happen to be avid readers of the magazines!

\section{Innovations in language teaching and learning}

CReW RD addresses the challenges faced by educators in organizing activities that incorporates reading, writing, drawing and other soft skills such as leadership and collaborative learning. Materials and activities can be adapted according to the needs of their institution and the levels of the target group. CReW RD explores the use of Reader's Digest magazines outside the classrooms in an enjoyable manner. Building from an experiential research among UiTM students (Wan Zumusni, Norhaiyati and Wan Aida, 2005), CReW RD incorporates various elements such as team building, collaborative 


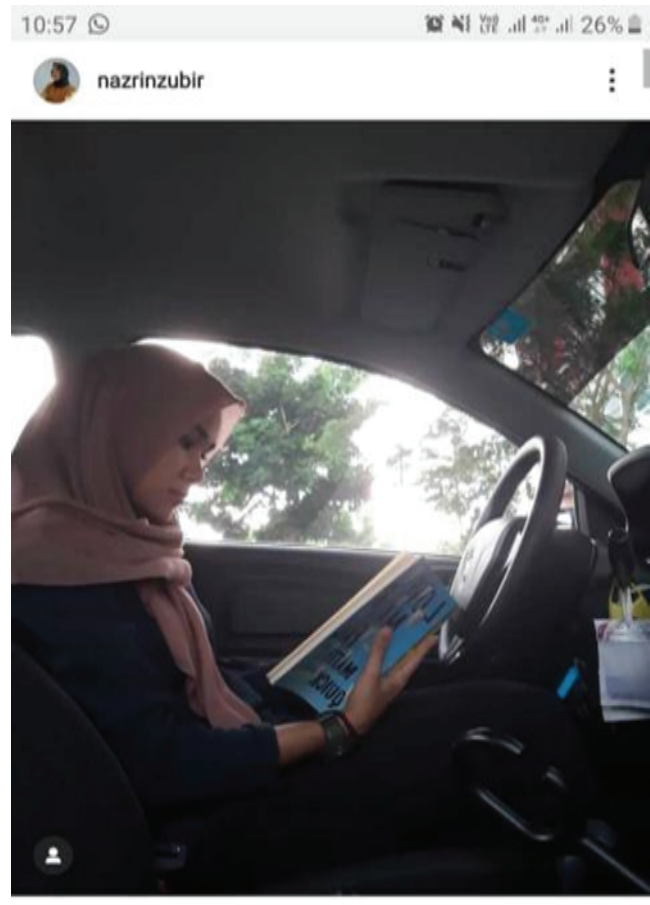

$0 \bigcirc \nabla$

QD2 Liked by amirulyunus and 202 others nazrinzubir Today a reader tomorrow a leader.

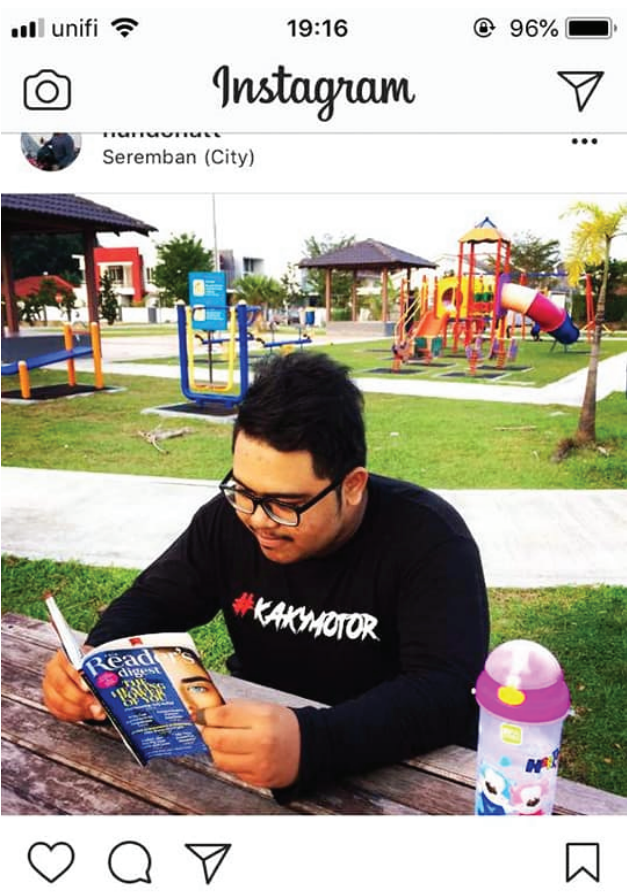

nundonatt "There is no friend as loyal as a book." - Ernest Hemingway \#weekwithoutwalls \#uitmseremban3

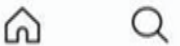
$\oplus \quad 9$
2

Figure 8: Students share their reading activities on their social media
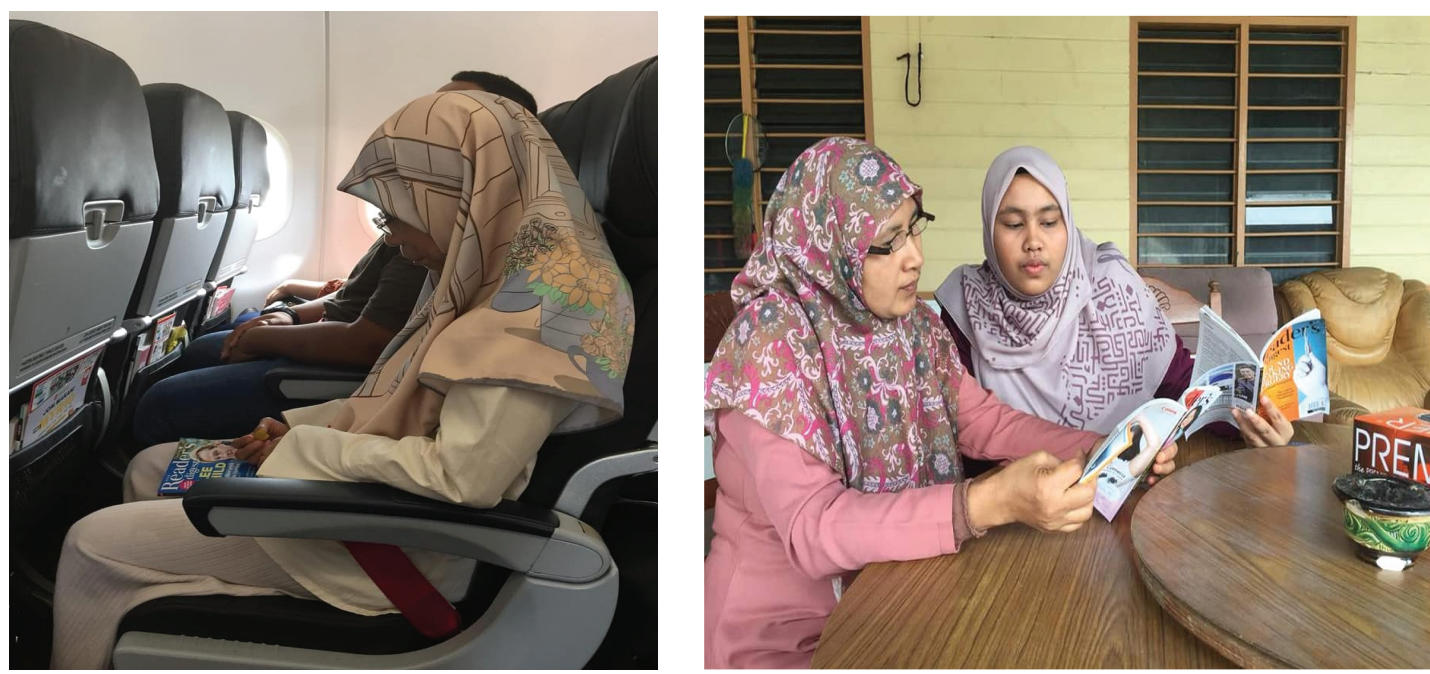

Figure 9: Students share their reading activities with their mothers

learning and problem-based learning while boosting their vocabulary, critical thinking and creative writing skills. The researchers also applied for copyright of CReW RD and has developed an indoor board game. CReW RD has also won gold and silver awards in several international innovation, invention and design competitions. 


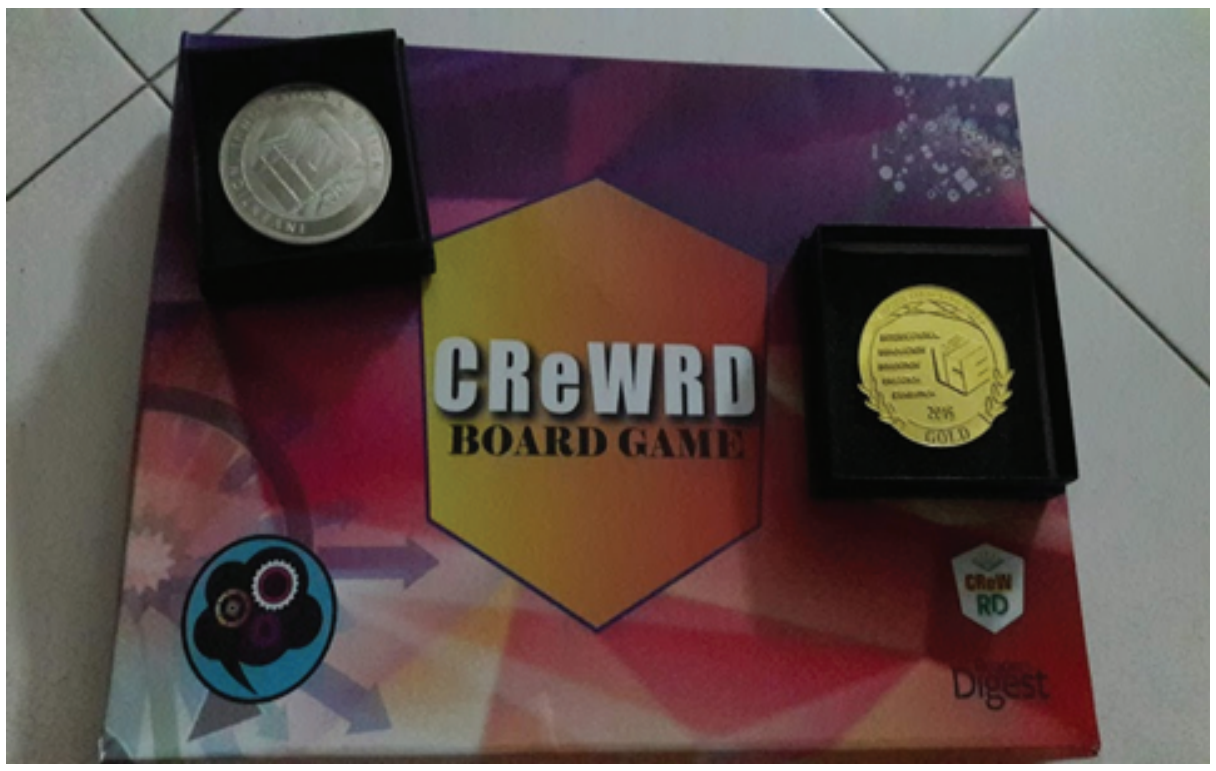

Figure 10: CReW Boardgame

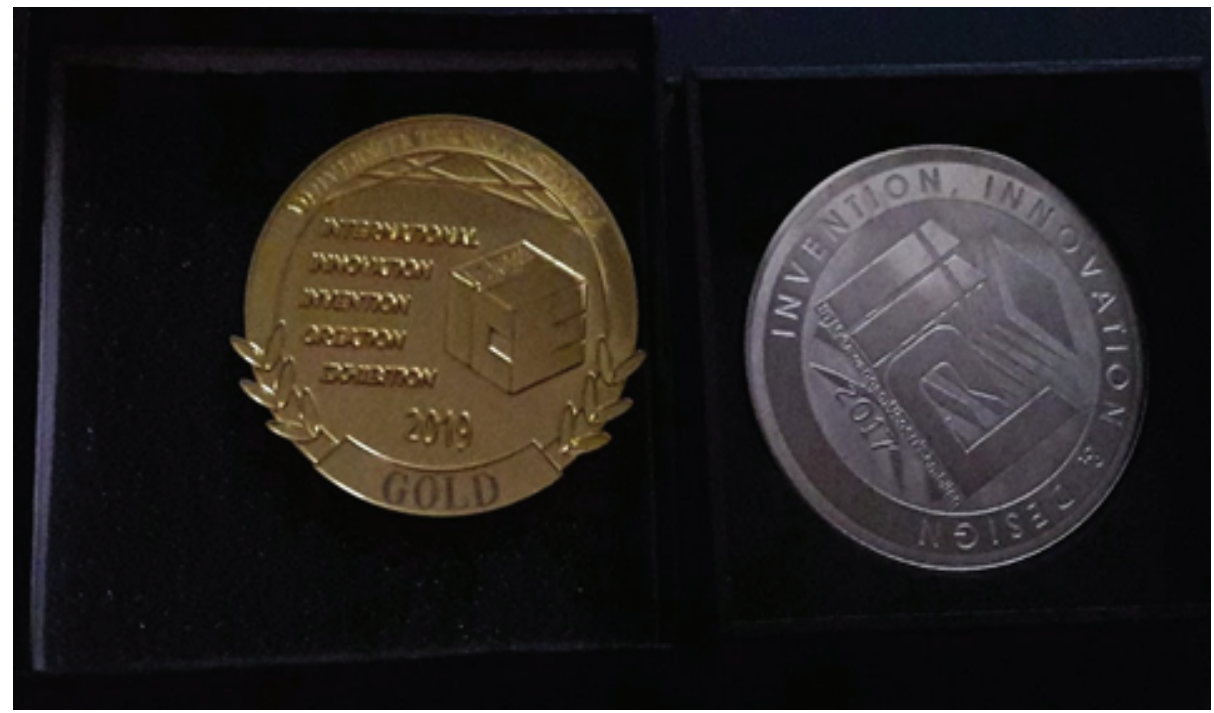

Figure 11: CReW gold and silver awards

Innovation in teaching and learning is achieved by introducing or implementing a new method or tool to enhance the process of teaching and learning. It can be in the form of a major or minor change in the course content, a new method or approach in teaching, a new activity carried out, and a new form of instructional materials developed and used such as video, film, software, online program, or an assessment procedure introduced in the course (HEA, 2014). 


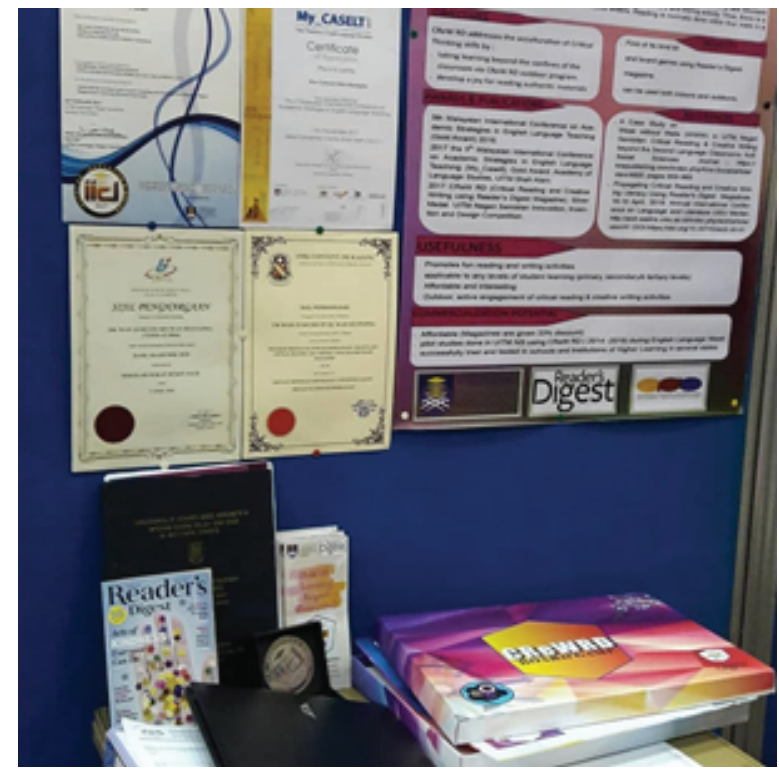

Figure 12: CReW in international innovation, invention and design competitions

\section{Discussion}

CReW RD promotes learning beyond classroom and enhances students' creativity, leadership skills, communication skills and soft skills while doing the activities. It caters to the total physical, mental and emotional responses of language learners towards second or foreign language learning. Students learn critical academic reading as a subject in the classroom but having Reader's Digest magazines to be read outside the classroom and participate in the outdoor CReW RD allows them to learn more than just critical academic reading and vocabulary. At the same time, it does not put additional burden to teachers if they know how to integrate RD magazines into their classroom as an alternative or another resource for medium to high proficiency students.

When the students buy the Reader's Digest magazines, their motivation to read beyond the classroom would improve as the ownership attainment enforces reading outside the classroom (Reading Evidence on Reading for Pleasure, 2012). Therefore, teachers can motivate students to read beyond the classrooms in a fun, engaging and motivating reading program to cultivate a reading culture at schools and higher education institutions to prepare students not only to do well in examinations but in their soft skills. Reading and writing are no longer viewed as solitary, boring and individualized activities among ESL learners. 


\section{Conclusion}

The collaborations with Reader's Digest Asia Pacific, an international company and Express Subscriptions Sdn. Bhd. show the trust and acknowledgment for the efforts done at the university and school level. From an inspiring family magazine, Reader's Digest has been used inside and outside the English language classrooms in urban and rural schools and universities. The effectiveness was tested using an experimental research and a module was developed. It was later turned into a board game with a copyright. On a final note, I would like to share a social experiment I did during Eid Adha in a kampong in Kelantan. While waiting for the food to be served, I put RD magazine on the house veranda. A boy picked it up and began to read it. Look at his expressions. He was later joined by his brother and another guest. It shows how accessibility to reading materials can be a historical moment for a child. You can give a caption to each photo.
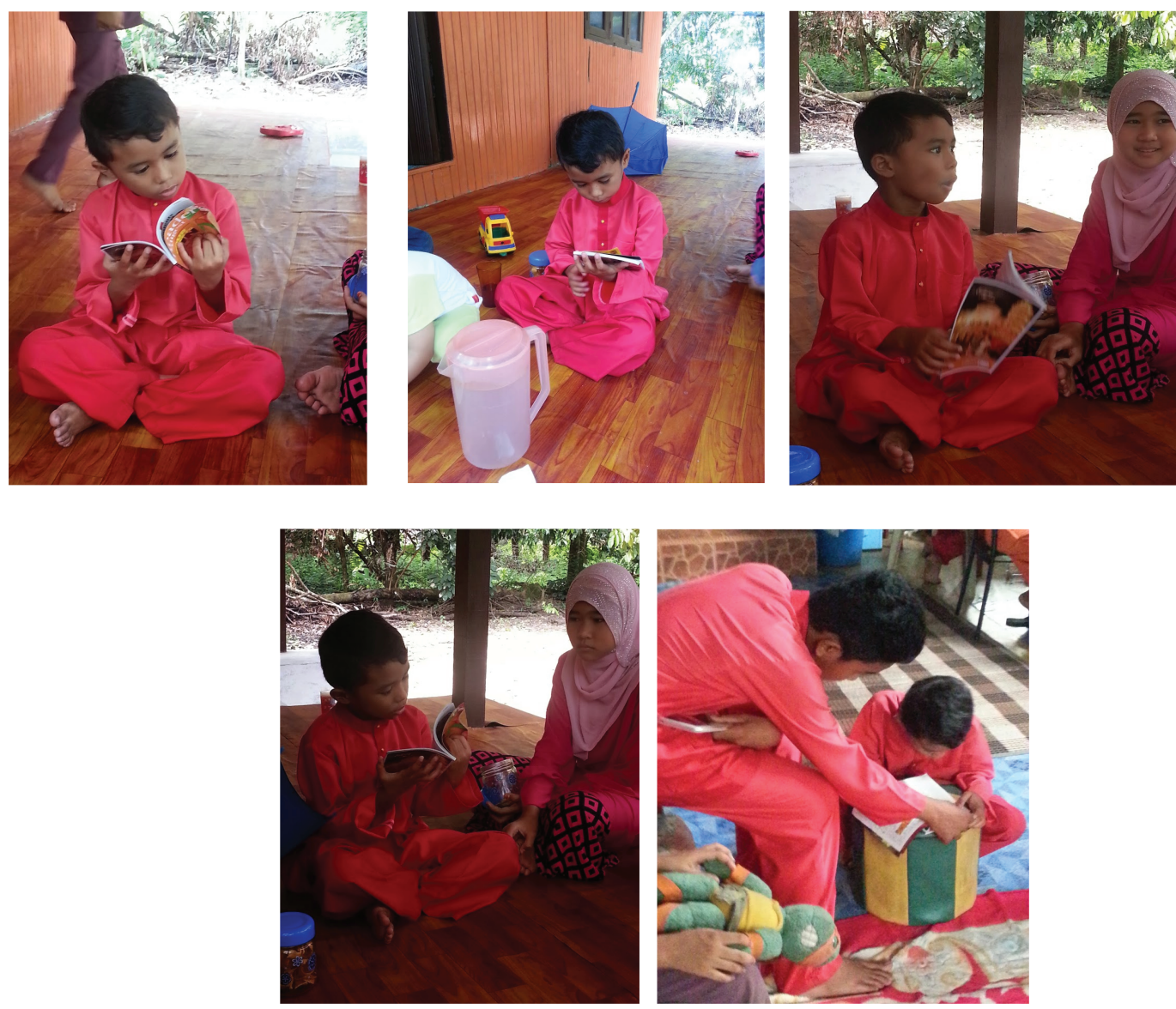


\section{Acknowledgements}

The author expresses much gratitude to Universiti Teknologi MARA for the support given in research grant and Reader's Digest Asia Pacific for free worksheets and the appointment as the spokesperson since 2016. Much thanks to Puan Latifah Abd Rahman, Express Subcriptions Sdn. Bhd. for giving student rate for the magazine.

\section{References}

[1] Akbari, O. and Razavi, A. (2016). Using Authentic Materials in the Foreign Language Classrooms: Teachers' Perspectives in EFL Classes. International Journal of Research Studies in Education, vol. 5, issue 2, pp. 105-116.

[2] Al-Nafisah, K. and Al-Shorman, R. A. (2011). Saudi EFL Students' Reading Interests. Journal of King Saud University - Languages and Translation, issue 23, pp. 1-9.

[3] Dhanapal, S. and Lim, C. C. Y. (2013). A Comparative Study of the Impacts and Students' Perceptions of Indoor and Outdoor Learning in the Science Classroom. Asia Pacific Forum on Science Learning and Teaching, vol. 14, issue 2, p. 1.

[4] Hopper, R. (2005). Adolescent Fiction Reading Habits and Reading Choices. Literacy, vol. 39, issue 3. pp. 113-120.

[5] Hussin, S., Maarof, N. and D'Cruz, J. V. (2000). Sustaining an Interest in Learning English and Increasing the Motivation to Learn English: An Enrichment Program. Retrieved from http://iteslj.org/Techniques/Hussin-Motivation/.

[6] Kelly, C., et al. (2002). Effective Ways to Use Authentic Materials with ESL/EFL Students. The Internet TESL Journal, vol. 8, issue 11, pp. 1-8.

[7] Lansford, L. (2014). Authentic Materials in the classroom: The Advantages. Cambridge Conversations. Retrieved from http://www.cambridge.org/elt/blog/2014/ 05/16/authenticmaterials-classroom-advantages/.

[8] Muchow, C. (2015). The Importance of Reading Outside the Classroom. Retrieved from http://emertainmentmonthly.com/index.php/the-importance-ofreadingoutside-the-classroom/.

[9] Nordin, R. and Eng, L. S. (2017) Text-Selection for Teaching Reading to ESL Tertiary Students: A Study on Genre and Content Preferences. Journal of Instruction, vol. 10, issue 1, pp. 71-84.

[10] Pandian, A. (2001). A Study on Readership Behavior among Multi-ethnic, MultiLingual Malaysian Students. Retrieved from http://ultibase.rmit.edu.au. 
[11] Pecorari, D., et al. (2011). English Textbooks in Parallel Language Education. TESOL QUARTERLY, vol. 45, issue 2, pp. 313-333.

[12] Polio, C. (2014). Using Authentic Materials in the Beginning Language Classroom. CLEAR News, vol. 18, issue 1, pp. 2-5.

[13] Pyle, K. (2010). Learning Outside the Classroom. Retrieved from https://www.nfer.ac. uk/pdf/LearningOutsidetheClassroom.pdf.

[14] Department of Education. (2012). Reading Evidence on Reading for Pleasure. Retrieved from https://www.gov.uk/government/publications/research-evidenceon-readingfor-pleasure.

[15] Richey, R. C. and Klein, J. D. (2005) Developmental Research Methods: Creating Knowledge from Instructional Design and Development Practice. Journal of Computing in Higher Education Spring, vol. 16, issue 2, pp. 23-38.

[16] Stoffelsma, L. and Spooren, W. (2017). Improving the Academic Reading Proficiency of University Students in Ghana: An Educational Design Research Approach. Language Matters, vol. 48, issue 1, pp. 48-70.

[17] Annamalai, S. and Muniandy, B. (2013). Reading Habit and Attitude among Malaysian Polytechnic Students. International Online Journal of Educational Sciences, vol. 5, issue 1, pp. 32-41.

[18] Ulper, H. (2011). The Motivational Factors for Reading in Terms of Students. Educational Sciences: Theory and Practice, vol. 11, issue 2, pp. 954-960.

[19] Valva, L. (2009). Benefits of Using Newspapers, Magazines and Books in Classroom. Linguistic and Communicative Performance Journal, vol. 2, issue 2, pp. 12-17.

[20] Mustapha, W., Ismail, N. \& Elias, S. (2009). The Effectiveness of Reader's Digest Worksheets in improving Reading Skills - a Case Study on MUET-taking Students. Academic Journal of Social Studies. vol. 9, issue 1. pp. 17-33. 